\title{
Early feeding patterns among Mexican babies: findings from the 2012 National Health and Nutrition Survey and implications for health and obesity prevention
}

Denise M. Deming ${ }^{1 *}$, Myriam C. Afeiche ${ }^{2}$, Kathleen C. Reidy ${ }^{1}$, Alison L. Eldridge ${ }^{2}$ and Salvador Villalpando-Carrión ${ }^{3,4}$

\begin{abstract}
Background: Feeding practices and dietary factors associated with obesity in young children are now recognized to begin in infancy. Yet little is known about what specific foods and beverages Mexican children are consuming during the rapid dietary changes occurring in the first few years of life. The objective of this study was to describe the transitions in food consumption patterns of Mexican children from birth up to age 4 years and to assess their adherence to feeding guidelines that support growth, development and obesity prevention.
\end{abstract}

Methods: We analyzed cross-sectional, 24-hour dietary recall data from a nationally-representative sample of infants ages $0-11.9$ months $(\mathrm{m})(n=411)$, toddlers ages 12-23.9 $\mathrm{m}(n=538)$, and preschoolers ages $24-47.9 \mathrm{~m}(n=1108)$ from the Mexican National Health and Nutrition Survey 2012 (NHNS 2012). The prevalence of foods and beverages was estimated for specific age categories of children useful for examining detailed transitions in food consumption patterns and compared to international feeding guidelines for infants and young children.

Results: Few infants were exclusively breastfed (15\% ages 0-3.9 m; $4 \%$ ages 4-5.9 m) and only 1 \% met the recommendation to exclusively breastfeed until at least age $6 \mathrm{~m}$. One to $10 \%$ of infants ages $<6 \mathrm{~m}$ and $14-38 \%$ of infants ages 6-11 $\mathrm{m}$ were fed cow's milk, a practice not recommended until after age 1 year. Most infants ages 0-3.9 $\mathrm{m}$ were meeting the recommendation to delay feeding of complementary foods until age $6 \mathrm{~m}$, but by the age of 4-5.9 m, 9-37\% of infants were fed foods from nearly all of the major food groups. Few infants ages 6-11.9 m received iron-rich foods, (3-4\% iron-fortified infant cereals; $2-18 \%$ meats). By the age of $9 \mathrm{~m}$, more children consumed any type of sweet (75\%) than consumed a distinct portion of fruit (54\%) or vegetable (25\%). Sweetened beverages were fed with an increasing prevalence from 6 to $42 \%$ in infancy, and reached $63 \%$ by age $12 \mathrm{~m}$ and $78 \%$ by age $24 \mathrm{~m}$.

Conclusions: These data show that dietary patterns begin very early in life and many infants, toddlers and preschoolers in Mexico are not meeting important feeding recommendations aimed at supporting healthy growth, development and obesity prevention. These findings are useful to support the ongoing promotion of evidence-based feeding guidelines for young Mexican children.

Keywords: Complementary feeding, Food consumption patterns, Mexico, Infants, Toddlers, Preschoolers

\footnotetext{
* Correspondence: denise.deming@rd.nestle.com

${ }^{1}$ Nestlé Nutrition Global R\&D, Florham Park, NJ, USA

Full list of author information is available at the end of the article
} 


\section{Background}

In the last few decades, Latin American countries have experienced dramatic increases in childhood overweight and obesity rates [1] due to a rapid shift in the composition of the diet, which may be due, in part, to rapid urbanization [2]. In Mexico, the national health and nutrition surveys over the past 24 years have shown a marked nutrition transition characterized by a steady decline in child undernutrition and a consistent increase in overweight and obesity at alarming rates in all age groups [3] with the highest reported rates of change in obesity prevalence in the world [4]. Among Mexican children, overweight and obesity rates increased from $26.9 \%$ in 1999 to $34.4 \%$ in 2012 among 5- to 11-year-olds and overweight increased from $7.8 \%$ in 1988 to $9.0 \%$ in 2012 in children under age 5 years [3]. This small albeit important increase in the prevalence of overweight in Mexico's youngest children contributes to the growing recognition that early childhood provides the best opportunity for addressing obesity prevention [5].

A substantial body of literature suggests that childhood overweight and obesity begins during the first few years of life [6-9] when parental practices, food preferences, and dietary habits are established [10-14]. Widespread consensus on feeding guidelines for infants and young children support exclusive breastfeeding until age 6 months followed by the introduction of appropriate complementary foods and continued breastfeeding up to two years or as long as mutually beneficial for mother and child [15-19]. These recommendations support optimal growth and development, the establishment of healthy eating habits and the prevention of obesity. Specific feeding practices and dietary factors associated with overweight/obesity in infants and young children such as lack/short duration of breastfeeding [20-23], early introduction to complementary foods [24-27], intake of sugar-sweetened beverages [28-30], and low fruit and vegetable consumption [31, 32], are now recognized to begin in infancy [9], and have been a focus in describing early dietary patterns in infants and young children from national dietary intake surveys in the United States (US) [33].

In Mexico, the trends from national surveys have reported deterioration in the rates of breastfeeding [34], inadequate timing of complementary feeding [35], low adherence to recommendations for fruit and vegetable intake [36, 37], and excessive consumption of sugarsweetened beverages [38], a problem that prompted the Mexican Ministry of Health to develop recommendations for beverage intake [4] and the Mexican government to institute a $10 \%$ excise tax on sugar-sweetened beverages. Whereas most public policies have focused on prevention of undernutrition, these efforts addressing excessive consumption of sugar-sweetened beverages target the widespread prevalence of obesity in Mexico, which is now recognized as an epidemic [1]. However, a substantive prevalence of undernutrition (stunting, anemia) still exists in some regions and population groups in Mexico, despite the decline in undernutrition in the past few decades [3]. Thus, it is essential to assess early childhood feeding practices within the context of the double burden of undernutrition and obesity facing the Mexican population.

There is an important and urgent need to understand the current food consumption patterns of Mexican children in the first few years of life in order to adequately address undernutrition and the increasing rates of childhood obesity in Mexico. Yet, little is known about what specific foods and beverages infants and young children are consuming at different ages during the rapid transition from an all milk diet to foods of the family table. The aim of this study is to use population-based data from the NHNS 2012 to describe the feeding practices and transitions in food consumption patterns of Mexican infants and young children. Additionally, we review the adherence to international feeding guidelines and the presence of eating patterns consistent with the feeding practices and dietary factors associated with early childhood obesity. The findings can be used to identify and show the magnitude of nutrition and dietary issues that begin during the early years of life and provide opportunities for health care practitioners and policy makers to promote evidence-based feeding guidelines for Mexican children. The findings can also provide baseline population-based data to evaluate public health programs and policies and government initiatives such as the 2014 excise tax on sugar sweetened beverages.

\section{Methods}

\section{Study design}

The Mexican NHNS 2012 (Encuesta Nacional de Salud y Nutrición (ENSANUT) 2012) is a cross-sectional, probabilistic, population-based survey designed by Mexico's National Institute of Public Health (Instituto Nacional de Salud Pública) to characterize the health and nutritional status of the Mexican population. The NHNS 2012 used a multi-stage, stratified, and clustered sampling system drawn to be representative of all states and four geographic regions in Mexico: a) North, b) Center, c) Mexico City, and d) South, by rural, urban and socioeconomic strata [39]. The data were collected during October 2011 through May 2012 from 50,528 Mexican households with a household response rate of $87 \%$. Informed consent was obtained for each eligible person $18 \mathrm{y}$ and older and for the father, the mother or the caretaker of participants under $18 \mathrm{y}$. Informed assent was collected in children and adolescents under age 18 years. The survey protocol and data collection instruments were approved by the Ethics 
Committee of the Mexican National Institute of Public Health. Additional details on the design, sampling procedures and survey methodology are described elsewhere [39].

\section{Study population}

We evaluated a stratified, nationally representative, subsample of 2057 children from birth up to age four years. The data are presented for 8 age groups including younger infants ages $0-3.9$ months $(n=107)$ and 4-5.9 months $(n=75)$, older infants ages $6-8.9$ months $(n=107)$ and 11.9 months $(n=122)$, toddlers ages 12-23.9 months $(n=538)$, and preschoolers ages 2435.9 months $(n=556), 36-47.9$ months $(n=552)$, and 24-47.9 months $(n=1108)$.

\section{Data collection methods}

A single 24-hour dietary recall (24HDR) was collected for each child by trained interviewers during a face-toface interview with the parent or caregiver; a second dietary recall for a randomly selected subsample of children (10\%) was collected on a different day. Parents or caregivers of each child reported all foods and beverages and the amount consumed of each food item for the previous 24-h period. To improve dietary recall data, the NHNS 2012 implemented an automated 5-step multiple-pass method and collected data on both weekday and weekend days. The 24 HDR data were also linked, for the first time, to a food and beverage composition table based on a compilation of the nutrient composition analyses conducted in Mexico and the food composition tables from the United States Department of Agriculture's Nutrient Database for Dietary Studies [40]. Data on breastfeeding practices in children ages 035.9 months were based on an infant feeding practices questionnaire implemented on the day of the 24HDR.

\section{Data analysis}

All foods and beverages reported in the 24HDR were assigned to food groups adapted from previous dietary intake studies in young children [11-14, 41]. Food groups were adjusted to incorporate local foods and reflect the relative role of specific types of foods and beverages in the diets of infants and young children living in Mexico.

Stata 13 (StataCorp, College Station, TX) was used to create data files, assign individual foods and beverages to food groups, and estimate the percentages of children who consumed foods from each food group. All estimates incorporated appropriate sample weights to reflect nationally representative results and to account for survey design.

All analyses were based on the single 24HDR completed for all children. The means estimated the proportions of children who consumed specific foods and beverages at least once in a day, and included all reported foods and beverages regardless of the amounts consumed. These estimates were based on foods 'as consumed' so food mixtures, e.g. soups or stews, were considered single food items and are not disaggregated into their respective ingredients.

\section{Adherence to feeding guidelines and assessment of feeding practices}

Feeding practices and food consumption patterns including breastfeeding and complementary feeding, were evaluated in accordance with international feeding guidelines proposed by the World Health Organization (WHO) $[15,16]$. We also acknowledge and discuss the existence of recommendations from other organizations [17-19] that concur with the WHO, and others [42, 43] that differ in some aspects.

\section{Results}

\section{Study population characteristics}

About $2 \%$ of the sample were wasted, $14 \%$ stunted, $3 \%$ underweight and $8 \%$ overweight (Table 1). A total of $70 \%$ lived in an urban area. Of the primary caregivers, most often the mother, $85 \%$ had an elementary and/or secondary education, $70 \%$ were unemployed, and $47 \%$ were married.

\section{Breastfeeding rates and consumption of milks}

Over $90 \%$ of children were ever breastfed, and the percentages who were currently breastfeeding decreased from birth through age 11 months and continued to drop from ages 12-35.9 months (Fig. 1). While only $15 \%$ of infants ages 0-3.9 months were currently exclusively breastfeeding, this rate fell to $4 \%$ among infants ages 4-5.9 months and to about $1 \%$ among ages 6-8.9 months.

The percentage of infants receiving breast milk remained higher than the percentage of those receiving iron-fortified infant formula for the first year (Table 2). However, the prevalence of breast milk fell early and precipitously from $89 \%$ in ages $0-3.9$ months to $43 \%$ in ages 9-11.9 months with a simultaneous drop in the prevalence of iron-fortified infant formula from $56 \%$ to $28 \%$ in these same age groups. A concurrent rise in the prevalence of cow's milk began in early infancy (1-10\% in ages 0-5.9 months) and escalated through late infancy (14-38\% in ages 6-11.9 months). By the age of 12 months, the most commonly consumed type of milk shifted from breast milk to cow's milk. Approximately $54 \%$ of toddlers and $58 \%$ of preschoolers consumed cow's milk at least once in a day, and full-fat was consumed more often than the reduced-fat version. Overall, while 95-100\% of infants received some type of milk or 
Table 1 Characteristics of Mexican children ages 0-47.9 months from the 2012 NHNS

\begin{tabular}{|c|c|c|}
\hline \multirow[b]{2}{*}{ Characteristic } & \multicolumn{2}{|c|}{ Sample $n=2057$} \\
\hline & $\mathrm{n}$ & $\%$ \\
\hline \multicolumn{3}{|l|}{ Gender } \\
\hline Male & 1074 & 52.2 \\
\hline Female & 983 & 47.8 \\
\hline \multicolumn{3}{|l|}{ Child weight status $^{a}$} \\
\hline Stunted & 284 & 13.8 \\
\hline Wasted & 29 & 1.4 \\
\hline Underweight & 53 & 2.6 \\
\hline Overweight & 173 & 8.4 \\
\hline Normal & 1629 & 79.2 \\
\hline \multicolumn{3}{|l|}{ Geographic area } \\
\hline Urban & 1448 & 70.4 \\
\hline Rural & 609 & 29.6 \\
\hline \multicolumn{3}{|l|}{ Region } \\
\hline North & 436 & 21.2 \\
\hline Center & 648 & 31.5 \\
\hline Mexico City & 290 & 14.1 \\
\hline South & 683 & 33.2 \\
\hline \multicolumn{3}{|l|}{ Socioeconomic level ${ }^{\mathrm{b}}$} \\
\hline Low & 751 & 36.5 \\
\hline Medium & 710 & 34.5 \\
\hline High & 597 & 29 \\
\hline \multicolumn{3}{|l|}{$\begin{array}{l}\text { Education of primary } \\
\text { caregiver }^{c}\end{array}$} \\
\hline Less than Elementary & 101 & 4.9 \\
\hline Elementary-Secondary & 1757 & 85.4 \\
\hline More than High School & 197 & 9.6 \\
\hline \multicolumn{3}{|l|}{ Primary caregiver employed ${ }^{c}$} \\
\hline Yes & 623 & 30.3 \\
\hline No & 1434 & 69.7 \\
\hline \multicolumn{3}{|l|}{$\begin{array}{l}\text { Marital status of primary } \\
\text { caregiver }^{c}\end{array}$} \\
\hline Married & 960 & 46.7 \\
\hline Separated or divorced & 133 & 6.5 \\
\hline Widowed & 49 & 2.4 \\
\hline Not married & 185 & 9 \\
\hline Partners living together & 730 & 35.5 \\
\hline
\end{tabular}

Table 1 Characteristics of Mexican children ages 0-47.9 months from the 2012 NHNS (Continued)

Beneficiary of assistance program $^{\text {d }}$

\begin{tabular}{lll} 
Food & 156 & 7.6 \\
Money & 354 & 17.2 \\
Medical & 74 & 3.6 \\
None & 1584 & 77 \\
\hline
\end{tabular}

aUsed WHO Child Growth Standards (WHO Anthro, version 3.2.2, January 2011) which include multiple growth classifications so total is $>100 \%$. Based on WHO $z$-scores as follows: stunted $=$ height-for-age $z$-score $<-2$; wasted $=$ weightfor-height $z$-score $<-2$; underweight $=$ weight-for-age $z$-score $<-2$; overweight $=$ based on BMl-for-age $z$-score $>2$; normal = not stunted, wasted, underweight, or overweight

${ }^{\mathrm{b}}$ Created using principal component analysis based on household and community characteristics, i.e. household flooring material, potable water, ownership of electrical home appliances including washing machine, refrigerator, stove, television, radio

${ }^{\mathrm{C}}$ Caregiver information from mother (61\%), father (14\%), or other (24 \%); 6 children missing caregiver data

${ }^{\mathrm{d}}$ Such as Oportunidadas or others. Child may be direct beneficiary and/or family may receive assistance

milk product, this percentage declined to $71 \%$ of children ages 24-47.9 months.

\section{Complementary foods}

Many types of complementary foods appeared in the diet in early infancy, and by the age of 4-5.9 months at least 9-37\% of infants consumed foods from each of the major food groups except meats and other protein sources (Fig. 2). Consumption of milk products (yogurt/ cheese) increased from $9 \%$ in ages $4-5.9$ months to $21 \%$ and $31 \%$ in the two older infant age groups. Twelve percent of infants ages 4-5.9 months consumed any type of grain product, a proportion which more than tripled to $37 \%$ in ages $6-8.9$ months and reached $63 \%$ in ages 9-11.9 months. Yet, the rate of infant cereal consumption was only $6-10 \%$ in infants ages $4-11.9$ months, and only 1-4 \% of infants consumed iron-fortified infant cereal (Table 3). Fruits and $100 \%$ fruit juices consumed as distinct food items were the most commonly consumed food group among infants ages 4-5.9 months (37\%) and ranked high in ages 6-8.9 months (51\%) and 9-11.9 months (60\%). Vegetables consumed as distinct food items were minimal in infants ages $0-3.9$ months and rose to $23 \%$ in ages $4-5.9$ months, and $18 \%$ to $25 \%$ in the two older age groups. Few infants consumed meats and other protein sources before age 6 months, yet consumption increased to a third and almost one half of children in the two older age groups, respectively. Mixed dishes were among the most frequently consumed foods from age 6-8.9 months, surpassed only by sweets by the age 9 months. Sweets were introduced early, between ages 0-3.9 months, increased throughout infancy, and were consumed more often than any other food group between ages $9-11$ months. 


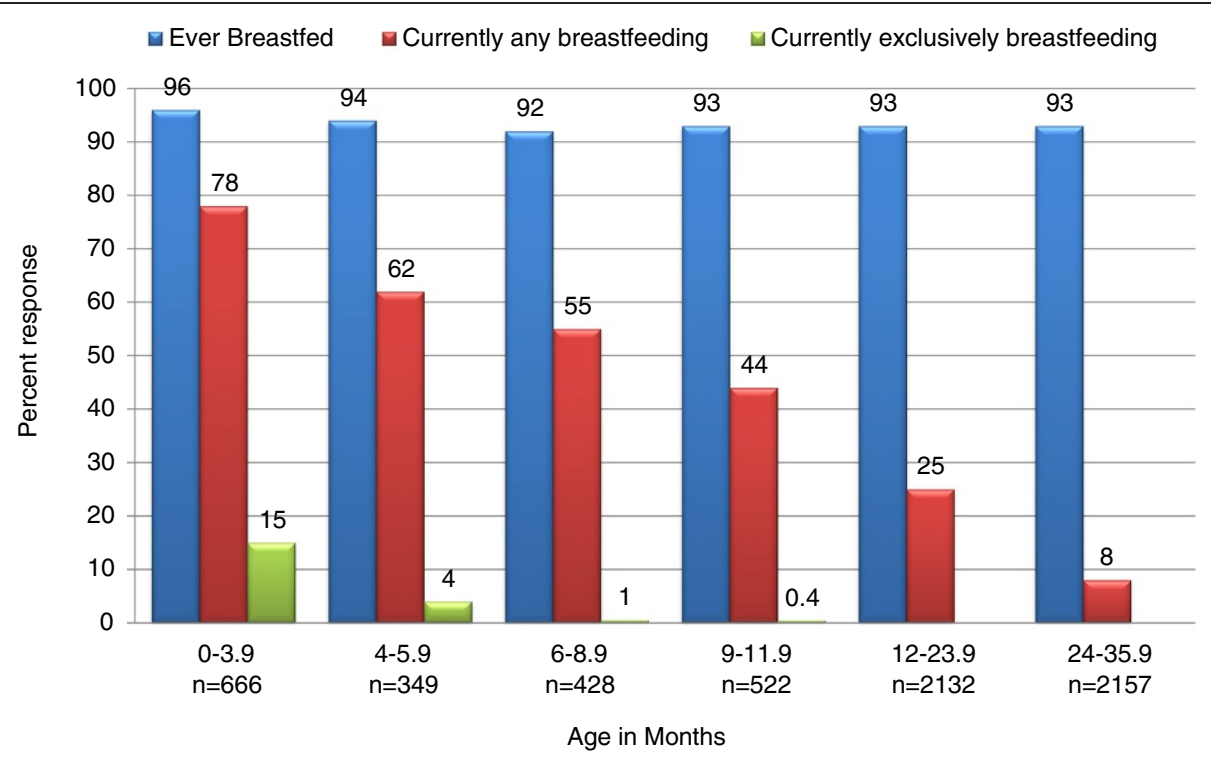

Fig. 1 Breastfeeding rates of Mexican infants, toddlers and preschoolers by age groups, Mexican NHNS, 2012. Bars represent the parent/caregiver response to the following questions from the Infant feeding Practices Questionnaire: "How many months did you breastfeed your child? "Ever Breastfed/Initiation of Breastfeeding); "Do you currently breastfeed your child?" (Currently Any Breastfeeding); Did you give your child any water, other milks, foods, other beverages yesterday, sometime during the day or at night? (Currently Exclusively Breastfeeding = percentage with a 'no' response to all other beverages and foods)

\section{Grains and grain-based products}

Tables 3, 4, 5, 6, 7, and 8 provide detailed information on the specific types of foods and beverages consumed by children in all age groups. The percentage of children consuming any type of grain product increased progressively throughout infancy and plateaued at about $72 \%$ through ages 12-47 months (Table 3). Tortillas were the dominant grain product consumed by $29-46 \%$ of infants ages $6-11.9$ months and 57-61 \% of toddlers and preschoolers. Noninfant cereals and bread products were the next most commonly consumed grain products among toddlers $(12 \%, 6 \%$, respectively) and preschoolers (17\%, $10 \%$, respectively).

\section{Fruits and vegetables}

The percentages of children who consumed fruits, $100 \%$ fruit juices (Table 4), and vegetables (Table 5) reflect the prevalence of these foods consumed as distinct food items and do not include the fruit or fruit juices or vegetables contained in food mixtures. One third of infants ages 4-5.9 months consumed any fruit as a distinct item and $15 \%$ consumed fruit juice on a given day. Roughly $45-50 \%$ of children ages 6-47.9 months consumed fruit on a given day and 7-17 \% of older infants, $18 \%$ of toddlers, and $13 \%$ of preschoolers consumed $100 \%$ fruit juice. Eighteen to $25 \%$ of older infants and $15-19 \%$ of toddlers and preschoolers consumed vegetables as distinct food items in a day.

\section{Meat and protein sources}

Consumption of meats and protein sources was minimal before age 6 months, 34-46 \% between ages 6-11.9 months, and 66-71 \% among toddlers and preschoolers (Table 6). Consumption of meat, specifically, was minimal up through the age of 8 months, rose to $18 \%$ among ages 9-11.9 months, and $\sim 26 \%$ among toddlers and preschoolers. Poultry was the most commonly consumed type of meat followed by beef and cold cuts, bacon and sausages. Eggs and egg dishes and beans and peas were the most commonly consumed nonmeat protein sources in the second half of infancy and in the toddler and preschooler stages.

\section{Mixed dishes}

Mixed dishes ranked among the top food groups consumed by the age of 6 months and through the toddler and preschooler stages. About $52-67 \%$ of older infants and $80-84 \%$ of toddlers and preschoolers consumed any type of mixed dish at least once in a day (Table 7). Protein mixed dishes, especially soups, stews and broths, were most commonly consumed among infants (42-54 \%) and toddlers (53\%), and similarly consumed as grainbased mixed dishes among preschoolers (53\% and $56 \%$ ).

\section{Sweets, sweetened beverages and salty snacks}

The consumption of energy-dense, nutrient-poor foods and beverages began in early infancy and increased rapidly with age especially after age 6 months (Table 8). 
Table 2 Percentage of Mexican children ages 0-47.9 months consuming milks and milk products ${ }^{a}$

\begin{tabular}{|c|c|c|c|c|c|c|c|c|}
\hline \multirow[b]{3}{*}{ Age, months } & \multicolumn{8}{|c|}{ Percent consuming at least once in a day } \\
\hline & \multicolumn{4}{|c|}{ Infants } & \multirow{2}{*}{$\frac{\text { Toddlers }}{12-23.9}$} & \multicolumn{3}{|c|}{ Preschoolers } \\
\hline & $0-3.9$ & $4-5.9$ & $6-8.9$ & $9-11.9$ & & $24-35.9$ & $36-47.9$ & $24-47.9$ \\
\hline N & 107 & 75 & 107 & 122 & 538 & 556 & 552 & 1108 \\
\hline Any milk or milk products ${ }^{b}$ & 100.0 & 97.6 & 94.5 & 94.5 & 86.2 & 74.9 & 67.3 & 71.3 \\
\hline Any milk & 100.0 & 97.6 & 92.6 & 92.3 & 80.5 & 66.5 & 60.9 & 63.9 \\
\hline Breast milk & 89.0 & 55.2 & 54.6 & 42.7 & 13.5 & 2.6 & 0.0 & 1.4 \\
\hline Infant formula ${ }^{d}$ & 55.7 & 45.9 & 44.6 & 27.5 & 22.7 & 6.1 & 2.7 & 4.5 \\
\hline Cow's milke & 0.9 & 9.8 & 14.0 & 38.3 & 54.0 & 57.9 & 57.6 & 57.8 \\
\hline Milk, fluid ${ }^{f}$ & 0.9 & 9.8 & 14.0 & 35.7 & 52.0 & 57.0 & 57.0 & 57.0 \\
\hline Milk, powdered ${ }^{9}$ & 0.0 & 5.2 & 10.2 & 26.0 & 20.3 & 11.4 & 8.1 & 9.9 \\
\hline Plain $^{h}$ & 0.9 & 9.5 & 13.2 & 37.3 & 49.2 & 46.3 & 38.4 & 42.6 \\
\hline Flavored milks' & 0.0 & 0.3 & 1.2 & 1.0 & 7.6 & 17.2 & 24.8 & 20.8 \\
\hline Whole & 0.9 & 7.5 & 12.9 & 37.4 & 48.3 & 52.7 & 53.6 & 53.1 \\
\hline Reduced-fat' & 0.0 & 2.3 & 1.2 & 2.4 & 6.5 & 3.4 & 2.5 & 3.0 \\
\hline Lactose-free & 0.0 & 0.0 & 0.0 & 0.0 & 0.8 & 2.7 & 2.2 & 2.5 \\
\hline Other milks ${ }^{k}$ & 0.0 & 0.0 & 1.0 & 2.3 & 1.8 & 3.2 & 1.0 & 2.2 \\
\hline Any milk products' & 0.0 & 8.9 & 20.7 & 30.9 & 32.4 & 30.0 & 25.4 & 27.9 \\
\hline Cheese & 0.0 & 0.0 & 2.7 & 5.8 & 8.3 & 11.9 & 9.6 & 10.8 \\
\hline Yogurt & 0.0 & 8.9 & 18.0 & 28.0 & 27.2 & 20.1 & 18.3 & 19.2 \\
\hline Baby yogurt & 0.0 & 8.9 & 10.8 & 20.1 & 17.6 & 11.9 & 8.5 & 10.3 \\
\hline
\end{tabular}

${ }^{a}$ Mean estimates by age group calculated from the 24-hour dietary recall, Mexican NHNS 2012

${ }^{\mathrm{b}} \mathrm{Sum}$ of all milks and milk products

'Sum of all milk beverages listed in the table; all values for powdered beverages are reconstituted

dIron-fortified

'Sum of any type of cow's milk including fluid and reconstituted, plain and flavored, whole and reduced fat, lactose-free

f Includes plain and flavored, whole, reduced fat, and lactose free

Includes plain and flavored, whole and reduced fat

${ }^{h}$ Includes fluid, powdered, whole, reduced fat and lactose-free

includes fluid, powdered, whole, reduced fat

Includes fluid and powdered, plain and flavored

k Includes soy and other animal milks

Includes cheese and yogurt consumed as distinct food items

Almost one half (44\%) to three quarters (75\%) of older infants ages 6-11.9 months, most toddlers (82\%) and nearly all preschoolers $(90 \%)$ consumed at least one type of sweet on a given day. This increase was concurrent with the dramatic rise in the prevalence of sweetened beverages from 6 to $42 \%$ during infancy, to $63 \%$ and $78 \%$ during the toddler and preschooler stages, respectively. Cookies, sweet breads, candy and salty snacks were commonly consumed during infancy and increased in popularity during the toddler and preschooler periods.

\section{Discussion}

This is the first study to our knowledge that describes, in detail, the transitions in food consumption patterns of a nationally-representative sample of infants and young children from birth up to age 4 years living in Mexico. Our findings provide a comprehensive picture of the changes in food consumption habits in the first few years of life and identify the magnitude of feeding and dietary issues including low breastfeeding rates, early introduction of cow's milk, early introduction of complementary foods, especially low consumption of iron-rich foods, low consumption of fruits and vegetables, and early and excessive consumption of sweets, especially sugar-sweetened beverages.

In this national sample, we see concerning percentages of children with conditions of undernutrition, especially stunting, and excess body weight and with caretakers who are predominantly single with limited education and incomes. As mentioned previously, Mexico is undergoing a nutrition transition characterized by declining rates of undernutrition in past decades and increasing rates of obesity in all age groups. It has been suggested that Mexico may be experiencing an advanced stage of the nutrition transition due to lower than expected 


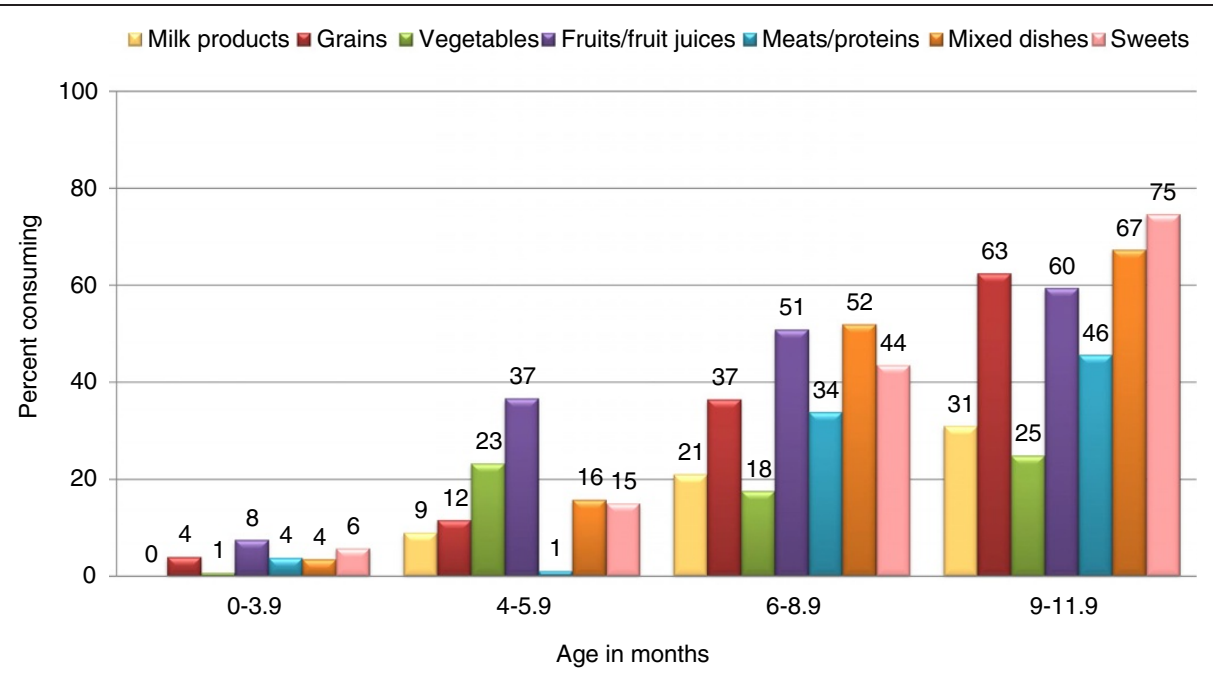

Fig. 2 Percentages of Mexican infants consuming any complementary foods by age groups, NHNS 2012. Milk products include cheese and yogurt. Sweets included any type of sweet, dessert or sweetened beverage

prevalences of the coexistence of the conditions at the household and individual levels, particularly overweight/ obesity with anemia and stunting in school-aged children [3]. Yet, the presence of the double burden at national, household and individual levels is an onorous public health concern and comprises a complex interplay of social, economic and political factors. The feeding practices and food consumption patterns of the infants and young children observed in our study are probably influenced by a range of environmental and behavioral factors that are likely shared by both conditions of undernutrition and obesity. These factors may include, but are not limited to, the mother's cultural beliefs, perceptions, knowledge, social support networks, and educational level, as well as household income, and socioeconomic resources [30, 44-49], which we describe in more detail in the context of our findings.

Breastfeeding is recognized as the ideal feeding choice for infants to achieve and maintain optimal health $[15,18]$, to reduce risk of morbidity and mortality [50] and to protect against overweight/obesity $[51,52]$. Breastfeeding has been associated with desirable feeding practices such as delaying introduction of solid foods [53] and less frequent offering of inappropriate

Table 3 Percentage of Mexican children ages 0-47.9 months consuming grains and grain products ${ }^{\mathrm{a}}$

\begin{tabular}{|c|c|c|c|c|c|c|c|c|}
\hline \multirow[b]{3}{*}{ Age, months } & \multicolumn{8}{|c|}{ Percent consuming at least once in a day } \\
\hline & \multicolumn{4}{|c|}{ Infants } & \multirow{2}{*}{$\frac{\text { Toddlers }}{12-23.9}$} & \multicolumn{3}{|c|}{ Preschoolers } \\
\hline & $0-3.9$ & $4-5.9$ & $6-8.9$ & $9-11.9$ & & $24-35.9$ & $36-47.9$ & $24-47.9$ \\
\hline N & 107 & 75 & 107 & 122 & 538 & 556 & 552 & 1108 \\
\hline Any grain or grain product ${ }^{b}$ & 4.0 & 11.6 & 36.5 & 62.5 & 70.8 & 72.6 & 72.1 & 72.4 \\
\hline Infant cereals & 0.4 & 6.1 & 7.3 & 10.2 & 3.3 & 1.9 & 0.9 & 1.4 \\
\hline Iron-fortified & 0.0 & 0.7 & 2.7 & 4.1 & 0.3 & 0.0 & 0.2 & 0.1 \\
\hline Non-infant cereals ${ }^{c}$ & 0.0 & 1.5 & 0.0 & 5.1 & 11.5 & 15.5 & 18.4 & 16.9 \\
\hline Bread and rolls $s^{d}$ & 2.2 & 0.0 & 4.5 & 4.8 & 6.4 & 9.3 & 11.5 & 10.3 \\
\hline Tortillas, plain ${ }^{e}$ & 1.4 & 4.0 & 29.0 & 46.1 & 57.4 & 62.2 & 59.1 & 60.7 \\
\hline Pasta and rice ${ }^{f}$ & 0.0 & 0.0 & 1.8 & 4.8 & 5.7 & 4.1 & 4.0 & 4.1 \\
\hline Pasta & 0.0 & 0.0 & 0.0 & 1.0 & 0.5 & 0.1 & 0.4 & 0.2 \\
\hline Rice & 0.0 & 0.0 & 1.8 & 3.7 & 5.2 & 4.0 & 3.6 & 3.8 \\
\hline
\end{tabular}

${ }^{\mathrm{a}}$ Mean estimates by age group calculated from the 24-hour dietary recall, Mexican NHNS 2012

${ }^{\text {b Sum of all food groups }}$

'Primarily ready-to-eat cereals

${ }^{\mathrm{d} A l s o}$ includes biscuits and bagels

e Includes masa, corn, and wheat

fPlain pasta and rice without toppings or additions 
Table 4 Percentage of Mexican children ages 0-47.9 months consuming fruits and $100 \%$ fruit juices ${ }^{a}$

\begin{tabular}{|c|c|c|c|c|c|c|c|c|}
\hline \multirow[b]{3}{*}{ Age, months } & \multicolumn{8}{|c|}{ Percent consuming at least once in a day } \\
\hline & \multicolumn{4}{|c|}{ Infants } & \multirow{2}{*}{$\frac{\text { Toddlers }}{12-23.9}$} & \multicolumn{3}{|c|}{ Preschoolers } \\
\hline & $0-3.9$ & $4-5.9$ & $6-8.9$ & $9-11.9$ & & $24-35.9$ & $36-47.9$ & $24-47.9$ \\
\hline N & 107 & 75 & 107 & 122 & 538 & 556 & 552 & 1108 \\
\hline Any Fruit or juice ${ }^{b}$ & 7.5 & 36.7 & 50.9 & 59.5 & 62.5 & 51.7 & 50.7 & 51.3 \\
\hline Any fruit ${ }^{c}$ & 7.5 & 33.8 & 48.3 & 53.6 & 55.3 & 46.3 & 44.3 & 45.4 \\
\hline Babyfood fruit & 3.7 & 15.0 & 12.6 & 8.2 & 1.8 & 0.7 & 0.0 & 0.4 \\
\hline Non-baby food fruit & 3.8 & 18.8 & 37.2 & 50.3 & 54.5 & 45.9 & 44.3 & 45.2 \\
\hline Fresh and frozen & 3.8 & 17.3 & 34.2 & 50.3 & 54.3 & 45.9 & 44.3 & 45.2 \\
\hline Bananas & 0.2 & 11.3 & 25.1 & 31.9 & 36.5 & 30.4 & 24.9 & 27.8 \\
\hline Pears & 0.9 & 2.3 & 3.2 & 6.6 & 2.5 & 2.1 & 2.9 & 2.5 \\
\hline Melons & 0.0 & 0.0 & 0.0 & 0.0 & 1.9 & 3.9 & 2.6 & 3.3 \\
\hline Guava & 0.0 & 0.0 & 0.0 & 1.3 & 2.8 & 1.0 & 1.3 & 1.2 \\
\hline Other fruits & 2.7 & 4.3 & 11.5 & 19.0 & 25.6 & 17.4 & 20.3 & 18.8 \\
\hline Canned & 0.0 & 1.5 & 3.0 & 0.0 & 0.3 & 0.0 & 0.0 & 0.0 \\
\hline Any $100 \%$ fruit juice & 0.0 & 15.3 & 7.5 & 17.3 & 18.0 & 12.6 & 12.8 & 12.7 \\
\hline Baby juice & 0.0 & 2.2 & 1.0 & 0.6 & 0.0 & 0.0 & 0.0 & 0.0 \\
\hline Non-baby juice & 0.0 & 13.1 & 6.5 & 16.7 & 18.0 & 12.6 & 12.8 & 12.7 \\
\hline
\end{tabular}

${ }^{a}$ Mean estimates by age group calculated from the 24-hour dietary recall, Mexican NHNS 2012

${ }^{b}$ Sum of all fruit and $100 \%$ fruit juice food groups

'Types of baby food fruit and non-baby food fruit include apple, banana, berries, grapefruit, gunabana, kiwi, mango, melon, orange, papaya, passion fruit, pear, peach, pineapple, plum, tropical fruit, watermelon

high-sugar, high-fat foods [54]. Early exposure to flavor compounds from breast milk may modify future flavor and food acceptance [55], and thus duration of breastfeeding may positively shape children's food preferences and food variety [56]. The WHO recommends exclusive breastfeeding up to age 6 months followed by the introduction of appropriate complementary foods and continuing as long as mutually beneficial for the mother and child $[15,16]$. Breastfeeding exclusively for 6 months is a desirable goal $[15,17,18,42]$, yet partial breastfeeding and

Table 5 Percentage of Mexican children ages 0-47.9 months consuming vegetables and $100 \%$ vegetable juices $^{a}$

\begin{tabular}{|c|c|c|c|c|c|c|c|c|}
\hline \multirow[b]{3}{*}{ Age, months } & \multicolumn{8}{|c|}{ Percent consuming at least once in a day } \\
\hline & \multicolumn{4}{|c|}{ Infants } & \multirow{2}{*}{$\frac{\text { Toddlers }}{12-23.9}$} & \multicolumn{3}{|c|}{ Preschoolers } \\
\hline & $0-3.9$ & $4-5.9$ & $6-8.9$ & $9-11.9$ & & $24-35.9$ & $36-47.9$ & $24-47.9$ \\
\hline N & 107 & 75 & 107 & 122 & 538 & 556 & 552 & 1108 \\
\hline Any vegetables ${ }^{b}$ & 0.7 & 23.3 & 17.6 & 24.9 & 15.8 & 18.5 & 20.5 & 19.4 \\
\hline Baby/toddler food & 0.2 & 12.1 & 2.1 & 1.8 & 0.8 & 0.0 & 0.0 & 0.0 \\
\hline Non-baby/toddler & 0.5 & 11.5 & 15.5 & 23.5 & 15.1 & 18.5 & 20.1 & 19.2 \\
\hline Cooked & 0.5 & 1.2 & 8.6 & 10.7 & 7.3 & 11.4 & 12.9 & 12.1 \\
\hline Dark green & 0.0 & 0.0 & 0.0 & 0.0 & 0.4 & 0.3 & 0.4 & 0.3 \\
\hline Deep yellow/orange & 0.0 & 0.0 & 6.2 & 6.2 & 4.9 & 6.5 & 7.8 & 7.1 \\
\hline Starchy & 0.0 & 0.0 & 4.0 & 3.3 & 4.5 & 6.0 & 7.3 & 6.6 \\
\hline Other vegetables & 0.5 & 1.2 & 2.4 & 1.9 & 1.7 & 4.3 & 3.2 & 3.8 \\
\hline Raw & 0.0 & 10.7 & 6.8 & 13.9 & 9.6 & 7.8 & 8.5 & 8.1 \\
\hline Any $100 \%$ vegetable juice ${ }^{c}$ & 0.0 & 2.3 & 0.0 & 0.3 & 0.1 & 0.0 & 0.4 & 0.2 \\
\hline
\end{tabular}

${ }^{a}$ Mean estimates by age group calculated from the 24-hour dietary recall, Mexican NHNS 2012

${ }^{\mathrm{b}}$ Types of baby/toddler vegetable and non-baby/toddler vegetables reported include dark green: quintoles, spinach, quelites, broccoli, chard; deep yellow: carrots, calabaza, pumpkin, sweet potato (camote); starchy: potatoes (French fries or fried, pureed, plain), potato tortilla, corn on the cob (elote), corn kernels (esquite); all other vegetables: (beet, cabbage, cactus, cauliflower, chayote, cucumber, green beans, jicama, mushrooms, onions, prickly pear cactus, tomato, vegetable pear (chayote), verdolaga, watercress, zucchini)

Includes fresh and commercial (canned) juices 
Table 6 Percentage of Mexican children ages 0-47.9 months consuming meats or protein sources

\begin{tabular}{|c|c|c|c|c|c|c|c|c|}
\hline \multirow[b]{3}{*}{ Age, months } & \multicolumn{8}{|c|}{ Percent consuming at least once in a day } \\
\hline & \multicolumn{4}{|l|}{ Infants } & \multirow{2}{*}{$\frac{\text { Toddlers }}{12-23.9}$} & \multicolumn{3}{|c|}{ Preschoolers } \\
\hline & $0-3.9$ & $4-5.9$ & $6-8.9$ & $9-11.9$ & & $24-35.9$ & $36-47.9$ & $24-47.9$ \\
\hline N & 107 & 75 & 107 & 122 & 538 & 556 & 552 & 1108 \\
\hline Any meat or protein source & 3.8 & 1.1 & 33.9 & 45.7 & 66.3 & 71.9 & 69.6 & 70.8 \\
\hline Babyfood meats & 0.2 & 0.0 & 1.5 & 1.8 & 0.4 & 0.0 & 0.0 & 0.0 \\
\hline Non-babyfood meats & 0.0 & 0.0 & 5.0 & 18.4 & 25.2 & 29.5 & 22.0 & 25.9 \\
\hline Beef & 0.0 & 0.0 & 0.3 & 8.0 & 2.0 & 6.7 & 6.2 & 6.5 \\
\hline Chicken or turkey & 0.0 & 0.0 & 3.2 & 7.4 & 15.6 & 12.5 & 9.6 & 11.1 \\
\hline Fish and shellfish & 0.0 & 0.0 & 0.0 & 0.8 & 1.3 & 2.5 & 2.0 & 2.3 \\
\hline Game & 0.0 & 0.0 & 0.0 & 0.0 & 0.5 & 0.8 & 0.6 & 0.7 \\
\hline Cured meats ${ }^{b}$ & 0.0 & 0.0 & 1.6 & 2.3 & 8.1 & 8.2 & 3.1 & 5.8 \\
\hline Organ meats & 0.0 & 0.0 & 0.0 & 0.0 & 0.0 & 0.1 & 0.1 & 0.1 \\
\hline Pork/ham & 0.0 & 0.0 & 0.0 & 0.0 & 0.8 & 1.1 & 1.6 & 1.3 \\
\hline Dried beans and peas & 1.4 & 0.0 & 18.2 & 11.5 & 26.3 & 28.5 & 32.4 & 30.4 \\
\hline Eggs and egg dishes & 2.2 & 1.1 & 12.8 & 21.2 & 35.4 & 40.0 & 40.2 & 40.1 \\
\hline Peanut butter, nuts, seeds & 0.0 & 0.0 & 0.0 & 0.0 & 0.4 & 4.5 & 1.9 & 3.3 \\
\hline
\end{tabular}

${ }^{a}$ Mean estimates by age group calculated from the 24-hour dietary recall, Mexican NHNS 2012

bIncludes cold cuts, bacon, sausage

breastfeeding for shorter periods of time are valued feeding choices [42].

Whereas breastfeeding is recognized as the ideal feeding choice [57], the rates in Mexico, especially those for exclusive breastfeeding, continue to decline. A recent study using data from the NHNS 2012 reported a marked deterioration of exclusive breastfeeding in Mexican infants under age 6 months from $22.3 \%$ to $14.5 \%$ between 2006 and 2012 [34]. Our study further shows that the rate of exclusive breastfeeding peaks at $15 \%$ in the first three months of life, plummets to $4 \%$ in ages 4-5.9 months and declines further to $\sim 1 \%$ in ages 6-8.9 months. These declining rates are considerably lower than those of any breastfeeding from $78 \%$ down to $62 \%$ and $55 \%$ in the same age groups. The overall decline in exclusive breastfeeding could, in part, be related to the early introduction of other beverages such as water (prevalence of $20 \%$ and $45 \%$ of infants ages 0-3.9 months and 4-5.9 months, respectively; data not shown), and sugar-sweetened tea/coffee as well as complementary foods among some infants. Additional factors affecting breastfeeding practices could be related to changes in perceptions due to the migration from rural areas where breastfeeding is considered to be more 'natural' to urban cities where life is faster and there is a perception of a non-breastfeeding culture, i.e., breastfeeding is getting lost as fewer women see other women breastfeeding, which may explain their embarrassment to breastfeed in public [46]. Moreover, the findings on breastfeeding could be a response to the Mexican
Ministry of Health's recommendation for breastfeeding initiated prior to the NHNS 2012 data collection period, which was to exclusively breastfeed from birth until age 4 to 6 months [58], and was subsequently changed to age 0 to 6 months in 2012 [17].

The overall drop in breastfeeding rates in our study is consistent with the pattern of decreasing percentages of infants who received breast milk. While infant formula use was high in early infancy, consumption also decreased over the first year of life as cow's milk, considered an inappropriate milk for children under age 1 year $[16,17,19]$, was fed to increasing percentages of infants. Communication of the guideline to delay feeding cow's milk to infants is important, since some Mexican mothers think that if whole cow's milks are fortified, they can be given to babies under 1 year [46]. Early feeding of cow's milk is associated with an increased risk of developing iron-deficiency anemia (IDA) [59], a concern especially in Mexico, where IDA is a prevalent (23\%) public health problem in young children ages 1 to 4 years [60] at all socioeconomic levels [61] and given the potential serious and irreversible consequences of IDA on physical and cognitive development and long term health of children [62].

The timely introduction of complementary foods is essential to fulfill the nutritional and developmental needs of a child and to facilitate the rapid transition from consuming milks to foods consumed by the family. Both early (younger than 6 months) and late (older than 6 months) complementary feeding can have undesirable 
Table 7 Percentage of Mexican children ages 0-47.9 months consuming mixed dishes ${ }^{a}$

\begin{tabular}{|c|c|c|c|c|c|c|c|c|}
\hline \multirow[b]{3}{*}{ Age, months } & \multicolumn{8}{|c|}{ Percent consuming at least once in a day } \\
\hline & \multicolumn{4}{|l|}{ Infants } & \multirow{2}{*}{$\frac{\text { Toddlers }}{12-23.9}$} & \multicolumn{3}{|c|}{ Preschoolers } \\
\hline & $0-3.9$ & $4-5.9$ & $6-8.9$ & $9-11.9$ & & $24-35.9$ & $36-47.9$ & $24-47.9$ \\
\hline N & 107 & 75 & 107 & 122 & 538 & 556 & 552 & 1108 \\
\hline Any mixed dishes ${ }^{b}$ & 3.5 & 15.8 & 52.0 & 67.4 & 79.8 & 84.6 & 82.3 & 83.5 \\
\hline Any protein mixed dishes ${ }^{c}$ & 2.6 & 14.3 & 42.3 & 53.7 & 53.1 & 55.6 & 49.4 & 52.6 \\
\hline Beef or pork & 0.0 & 0.0 & 0.0 & 1.7 & 4.0 & 6.7 & 8.4 & 7.5 \\
\hline Chicken or turkey & 0.0 & 0.0 & 3.6 & 6.8 & 4.6 & 5.4 & 7.3 & 6.3 \\
\hline Fish or shellfish & 0.0 & 0.0 & 0.0 & 0.0 & 1.3 & 2.6 & 1.6 & 2.1 \\
\hline Soups, stews, broths & 2.6 & 14.3 & 38.7 & 51.7 & 47.4 & 44.7 & 36.3 & 40.7 \\
\hline Any grain mixed dishes ${ }^{d}$ & 0.8 & 4.6 & 13.7 & 22.7 & 43.8 & 56.5 & 55.7 & 56.2 \\
\hline Corn-based & 0.0 & 0.6 & 1.4 & 5.8 & 15.6 & 24.3 & 21.5 & 23.0 \\
\hline Meat tacos & 0.0 & 0.0 & 0.0 & 1.4 & 3.8 & 8.0 & 5.9 & 7.0 \\
\hline $\operatorname{Tacos}^{\mathrm{e}}$ & 0.0 & 0.6 & 0.0 & 2.4 & 4.9 & 7.5 & 5.4 & 6.5 \\
\hline Enchiladas & 0.0 & 0.0 & 0.0 & 1.5 & 1.7 & 2.9 & 5.6 & 4.2 \\
\hline Tortillas ${ }^{\mathrm{f}}$ & 0.0 & 0.0 & 0.3 & 0.2 & 1.0 & 2.4 & 3.0 & 2.7 \\
\hline Tamales & 0.0 & 0.0 & 1.1 & 0.2 & 4.9 & 6.1 & 3.7 & 5.0 \\
\hline Wheat-based & 0.8 & 3.7 & 7.0 & 5.6 & 19.6 & 24.8 & 29.4 & 27.0 \\
\hline Sandwiches ${ }^{9}$ & 0.0 & 0.0 & 0.0 & 0.0 & 7.1 & 16.7 & 19.6 & 18.0 \\
\hline Pasta mixed dishes & 0.8 & 3.7 & 7.0 & 5.2 & 12.9 & 8.7 & 10.9 & 9.7 \\
\hline Other grain-based & 0.0 & 0.0 & 0.9 & 2.8 & 1.4 & 0.5 & 0.2 & 0.3 \\
\hline Rice mixed dishes & 0.0 & 0.3 & 5.6 & 9.4 & 16.4 & 17.1 & 16.5 & 16.8 \\
\hline
\end{tabular}

${ }^{a}$ Mean estimates by age group calculated from the 24-hour dietary recall, Mexican NHNS 2012

${ }^{\text {b}}$ Sum of protein and grain mixed dishes

'Sum of mixed dishes with meats and other sources of proteins as major ingredients and containing vegetables/rice/pasta/potatoes

${ }^{\mathrm{d}}$ Sum of corn-based, wheat-based, and rice mixed dishes

eIncludes vegetable and cheese

fWith fillings/toppings

${ }^{9}$ Also includes tortas, filled rolls

health outcomes [63]. Evidence suggests that early feeding of complementary foods puts infants at a higher risk for microbial infections, [51] and excess weight gain later in life [25-27]. Late feeding of complementary foods and/or reliance on poor quality foods increases an infant's risk of malnutrition, poor growth, and micronutrient deficiencies [64] and is a major cause of preventable mortality in young children [50]. National surveys in Mexico have shown the coexistence of early and late complementary feeding patterns [35]. Complementary feeding begins as early as age 3 to 5 months among some Mexican infants [34], and up to $92 \%$ of Mexican infants are fed complementary foods before age 6 months [35]. Yet, WHO indicators for measuring dietary diversity or late complementary feeding practices have shown improvement after age 6 months in Mexico [34, 35].

Our data confirm that from age 6 months many infants consumed a wide variety of complementary foods, and also show the magnitude of the alarming early feeding patterns before age 6 months. Moreover, we examine, in detail at the national level, the specific types of foods and beverages consumed by infants before age 6 months, which has been reported with varying degrees in other studies $[11,12,14,49]$. This early feeding pattern is consistent with the drop in exclusive breastfeeding after age 3 months described previously, and may be related to the perception of insufficient milk as a common reason for discontinuing breastfeeding [45], and to common beliefs that maternal milk is insufficient to satisfy baby's energy and nutritional needs and that early feeding of solids is seen as an accomplishment or indicator of infant maturity $[44,48]$.

Whereas delaying the introduction of complementary foods may be appropriate for younger infants, few infants in the second half of infancy, especially those 6-8.9 months of age, were fed iron-rich foods, a consumption pattern consistent with those observed by others, including the low rates of consumption of iron-rich foods and iron-fortified foods of only $54-56 \%[30,34,35]$ and inadequate iron intakes among Mexican infants ages 6-11.9 months [65]. Thus, the low prevalence of iron-fortified infant cereals and meats is a concern given the high risk of inadequate iron 
Table 8 Percentage of Mexican children ages 0-47.9 months consuming sweets and salty snacks ${ }^{a}$

\begin{tabular}{|c|c|c|c|c|c|c|c|c|}
\hline \multirow[b]{3}{*}{ Age, months } & \multicolumn{8}{|c|}{ Percent consuming at least once in a day } \\
\hline & \multicolumn{4}{|c|}{ Infants } & \multirow{2}{*}{$\frac{\text { Toddlers }}{12-23.9}$} & \multicolumn{3}{|c|}{ Preschoolers } \\
\hline & $0-3.9$ & $4-5.9$ & $6-8.9$ & $9-11.9$ & & $24-35.9$ & $36-47.9$ & $24-47.9$ \\
\hline N & 107 & 75 & 107 & 122 & 538 & 556 & 552 & 1108 \\
\hline Any sweet & 5.8 & 15.1 & 43.6 & 74.7 & 81.8 & 90.1 & 90.3 & 90.2 \\
\hline Cakes, pies, cookies & 0.0 & 1.9 & 20.6 & 33.7 & 33.7 & 29.8 & 27.0 & 28.5 \\
\hline Cookies & 0.0 & 1.6 & 20.6 & 33.7 & 30.8 & 27.2 & 24.5 & 25.9 \\
\hline Cakes & 0.0 & 0.3 & 0.0 & 0.4 & 3.3 & 3.2 & 2.6 & 2.9 \\
\hline Sweet breads, sweet rolls ${ }^{b}$ & 1.4 & 0.0 & 3.5 & 11 & 25.7 & 30.4 & 39.7 & 34.8 \\
\hline Candy, Mexican desserts & 0.0 & 1.6 & 2.6 & 13.4 & 20.4 & 24.5 & 27.6 & 26.0 \\
\hline Candy & 0.0 & 0.0 & 2.6 & 10.4 & 16.4 & 22.1 & 24.3 & 23.2 \\
\hline Mexican desserts & 0.0 & 1.6 & 0.0 & 3.0 & 4.2 & 2.8 & 3.9 & 3.3 \\
\hline Ice cream & 0.2 & 0.0 & 2.3 & 6.7 & 4.0 & 4.7 & 7.5 & 6.0 \\
\hline Sugar and syrups & 0.0 & 0.6 & 2.0 & 0.0 & 0.3 & 1.5 & 3.5 & 2.4 \\
\hline Sweetened beverages ${ }^{d}$ & 5.6 & 11.7 & 21.3 & 41.8 & 63.1 & 78.8 & 77.6 & 78.3 \\
\hline Fruit flavored drinks & 0.0 & 2.8 & 9.2 & 8.9 & 14.7 & 17.4 & 13.3 & 15.5 \\
\hline Carbonated sodas & 0.0 & 0.9 & 5.5 & 7.4 & 16.4 & 35.1 & 36.0 & 35.5 \\
\hline Sweetened tea/coffee & 5.6 & 3.0 & 4.4 & 13.7 & 22.3 & 23.7 & 28.7 & 26.1 \\
\hline Artificially sweetened ${ }^{e}$ & 0.0 & 0.0 & 0.0 & 0.4 & 2.7 & 2.3 & 1.9 & 2.1 \\
\hline Other beverages & 0.0 & 5.1 & 11.1 & 20.3 & 30.0 & 34.3 & 35.1 & 34.7 \\
\hline Atoles $^{f}$ & 0.0 & 3.5 & 4.1 & 9.3 & 10.7 & 9.5 & 9.0 & 9.3 \\
\hline Milkshakes $^{9}$ & 0.0 & 0.0 & 0.0 & 1.7 & 2.9 & 2.7 & 2.4 & 2.6 \\
\hline Yakult ${ }^{\text {h }}$ & 0.0 & 1.6 & 3.6 & 1.4 & 3.8 & 6.6 & 5.4 & 6.0 \\
\hline Aguas Frescas & 0.0 & 0.0 & 3.4 & 9.6 & 15.5 & 18.8 & 22.1 & 20.4 \\
\hline Salty snacks ${ }^{i}$ & 2.2 & 5.3 & 10.2 & 15.0 & 15.4 & 20.9 & 23.0 & 21.9 \\
\hline
\end{tabular}

${ }^{a}$ Mean estimates by age group calculated from the 24-hour dietary recall, Mexican NHNS 2012

bIncludes bunuelos, churros, doughnuts, pan dulce

${ }^{\mathrm{c}}$ Also includes frozen yogurt, puddings

${ }^{d}$ All are sugar-sweetened except for artificially sweetened

e Includes reconstituted powdered beverages

fWater and milk-based

${ }^{\mathrm{g}}$ Also includes smoothies and liquados

${ }^{h}$ Rice fermented lactobacillus

'From grains and starchy vegetables such as potato chips, fried corn snacks

intake among this age group and depending on whether older infants are fed breast milk or iron-fortified infant formula. Feeding iron-fortified complementary foods such as fortified infant cereals can be an effective strategy to prevent iron-deficiency in infants [16, 19, 66]. Pureed meats, especially beef, are recommended as a source of the highly bioavailable form of heme iron, and provide a developmentally-appropriate form for infants after age 6 months [19].

Daily consumption of a wide variety of fruits and vegetables is the foundation for a healthy diet. Thus, it is astounding that $\sim 50 \%$ of children ages $6-47.9$ months consumed no fruit and $\sim 80 \%$ consumed no vegetables both as distinct food items in a day. This low consumption may be related to the widespread lack of fruit and vegetable consumption among Mexicans of all ages [36, 37].
Additional factors to consider are that a child's food preferences may guide what foods the mother offers [44], and that household income and food cost/availability affect what specific foods [30, 44] as well as the variety of foods [44] that the family and thus the young child consumes. Soups, stews, and broths which often contain vegetables were among the most frequently consumed foods among children of all ages in our study. Thus, consumption rates of vegetables as well as fruits would likely be higher if their contributions from sources in other food groups, like mixed dishes, were considered. Mixed dishes contributed $39 \%$ of total vegetable intake among U.S. children ages 2 to 5 years [67]. Yet, most two- to three-year-olds still underconsume vegetables relative to U.S. dietary recommendations [68]. The apparent preference for fruit in Mexican children under age 4 years has also been 
reported in US [11-14] and Mexican [36] children. In contrast, a higher vegetable intake was observed in Mexican children with adequate body mass index (BMI) compared to those who were obese [36], which is consistent with other studies [31, 32]. In our study, larger percentages of children consumed fruit than $100 \%$ fruit juice, which is in line with recommendations to encourage consumption of whole fruit rather than juice and to limit fruit juice intake $[16,19]$.

The greatest cause for concern is the early introduction and sharp increase in the consumption of lownutrient, energy-dense sweets, sweetened beverages, and salty snack foods. Our data show that these foods comprise the most frequently consumed food group (other than milks) by the age of 9 months, and by the age of 2 years the vast majority of children consumed one or more types of sweets/sweetened beverages on a given day. This pattern may, in part, reflect cultural beliefs that some of these types of foods are satiating, i.e. 'stick to the stomach' or acceptable as occasional treats or comfort foods [44]. It is sobering to see in our study that between the ages of 9-11.9 months, more children consumed any type of sweet (75\%) in a day than consumed a distinct portion of fruit $(54 \%)$ or vegetable (25\%), a consumption pattern reported by the age of 2 years in U.S. children [13]. The pattern is also consistent with an increase in snacking among Mexican children ages 2 to 5 years between 1988 and 2012 during which calories from snacking (\% of total energy) increased from 12 to $20 \%$ [69]. Early complementary feeding may be a risk factor for consumption of noncarbonated sweetened drinks and high-fat snacks (30]. Consumption of sugar-sweetened beverages has been positively associated with overweight and adiposity in infants [30] and toddlers, as well as preschool children [28, 29]. Data from our study and other studies $[11,12,14,30,49]$ confirm that even very young infants are consuming sweets and sugar-sweetened beverages.

We acknowledge that our study has limitations and strengths. The NHNS 2012 is a cross-sectional, observational study of proxy-reported data, which may be subject to measurement error. This could be due, in part, to respondent burden for recalling the food and beverages that were fed to their young child. Additionally, the sample size in some of the age groups (e.g. $n=75$ ages 4-5.9 months) could also be a limitation in achieving unbiased prevalence estimates. We used a single 24HDR, which may not reflect usual intake, but the dietary data are based on valid methods (e.g. trained interviewers conducting interviews on both weekday and weekend days, use of an automated 5step multi-pass method) for estimating food intake of population groups. The $24 \mathrm{HDR}$ is accepted as the most thorough, comprehensive, and complete dietary intake instrument that exists to date [70, 71], but there may be methodological concerns related to dietary intake data collection in countries undergoing rapid nutrition transitions that were not considered [72].

Nevertheless, the NHNS 2012 provides the most comprehensive dietary intake data for the Mexican population. A major strength of our study is the use of specific age categories and food groups to describe, in detail, the transitions in food consumption patterns of a nationally representative sample of Mexican infants and young children from birth up to age 4 years. The dietary data also provide baseline population-based food consumption patterns to evaluate public health programs and policies changed or initiated after data collection in May 2012, such as the $10 \%$ excise tax on sugar-sweetened beverages in 2014.

Our study has implications for future research. Differences in breastfeeding practices, timing of complementary feeding, consumption of vegetables, fruits, high-fat snacks and juices were found among three cities in different regions of Mexico [30]. This warrants further studies examining differences in feeding practices and food consumption patterns across subpopulations of infants and young children such as socioeconomic groups, and urban versus rural locations or geographical regions of Mexico. There is also a need to understand the factors that influence the way Mexican mothers feed their children and the barriers for adopting improved feeding practices.

\section{Conclusions}

Developing healthy eating habits early in life is important for a child's growth and development and long term health [10]. Approaches to optimizing growth and development, and preventing obesity in infants and young children need to address the infant feeding and dietary patterns which begin at an early age. These new findings from the Mexican NHNS 2012 highlight alarming feeding and dietary issues that emerge before 12 months of age, develop rapidly during the second year of life, and persist through the first few years of life. The data identify areas that require urgent consideration, including promoting and supporting breastfeeding, delaying introduction of cow's milk, promoting age-appropriate introduction of complementary foods, including iron-rich foods such as iron-fortified infant cereals and meats, increasing consumption of fruits and vegetables, and delaying and limiting the feeding of sweets, especially sugar-sweetened beverages.

Strategies to ameliorate undernutrition and prevent obesity need to include specific objectives in terms of breastfeeding and appropriate introduction of complementary foods with goals of changing the inadequate dietary patterns identified in infants and young children 
living in Mexico. It is critical to acknowledge the importance of creating greater awareness that food preferences and dietary patterns start very early in life and can confer a high risk for long term health. This provides opportunities for health care practitioners to encourage parents of very young children in the development of healthful eating patterns and is useful for policy makers in promoting specific evidence-based feeding recommendations and dietary guidelines, and in designing and implementing programs and policies for improving the diets and health of millions of infants and young children in Mexico.

\section{Abbreviations \\ NHNS 2012: National Health and Nutrition Survey 2012; 24HDR: 24-hour} dietary recall; WHO: World Health Organization; IDA: iron-deficiency anemia.

\section{Competing interests}

The authors declare they have no competing interests. The opinions expressed are those of the authors alone and do not necessarily reflect the views or recommendations of their respective affiliations.

\section{Authors' contributions}

$\mathrm{DMD}$ and KCR conceived the study and designed the food groups, the food and beverage classification, and data analysis. DMD, MCA, KCR, ALE, SV-C contributed to the interpretation of the data. DMD wrote the initial draft of the manuscript and together with MCA, KCR, ALE, SV-C contributed to the critical evaluation of revisions and content. DMD, MCA, KCR, ALE, SV-C read and approved the final manuscript and are responsible for the content.

\section{Authors' information}

SV-C is a full professor of Pediatric Gastroenterology and Nutrition, UNAM and Head of the Pediatric Gastroenterology and Nutrition Department at the Children's Hospital of Mexico, National Institute of Health, Mexico City, Mexico

\section{Acknowledgements \\ Funding for this work was provided by the Nestlé Research Center, Lausanne, Switzerland. We thank Dr. Barry Popkin for insights from his years of experience with Mexican national surveys and access to investigate dietary patterns among Mexican infants and young children and Dr. Philip Bardsley for his expertise in statistical programming and knowledge of the Mexican national survey data. We also thank the University of North Carolina for providing access to the Mexican National Health and Nutrition Survey 2012 dataset and statistical programming for the data analysis.}

\section{Author details}

${ }^{1}$ Nestlé Nutrition Global R\&D, Florham Park, NJ, USA. ${ }^{2}$ Nestlé Research Center, Lausanne, Switzerland. ${ }^{3}$ Children's Hospital of Mexico, National Institute of Health, Mexico City, Mexico. ${ }^{4}$ Nestlé Infant Nutrition, Mexico City, Mexico.

Received: 8 July 2015 Accepted: 24 November 2015

Published online: 28 December 2015

\section{References}

1. Rivera JA, Gonzalez de Cossio T, Pedraza LS, Aburto TC, Sánchez TG, Martorell R. Childhood and adolescent overweight and obesity in Latin America: A systematic review. Lancet Diabetes Endocrinol. 2014:2:321-2.

2. Popkin BM, Adair LS, Ng SW. Global nutrition transition and the pandemic of obesity in developing countries. Nutr Rev. 2012;70(1):3-21.

3. Kroker-Lobos MF, Pedroza-Tobias A, Pedraza LS, Rivera JA. The double burden of undernutrition and excess body weight in Mexico. Am J Clin Nutr. 2014;100(6):1652S-8S.

4. Barquera S, Campos I, Rivera JA. Mexico attempts to tackle obesity: the process, results, push backs and future challenges. Obes Rev. 2013;14 Suppl 2:69-78.

5. Committee on Obesity Prevention Policies for Young Children. Early Childhood Obesity Prevention Policies. Washington DC: The National Academies Press; 2011
6. Durmus $B$, van Rossem $L$, Duijts $L$, Arends $L R$, Raat $H$, Moll HA, et al. Breastfeeding and growth in children under 3 years: the Generation $R$ Study. Br J Nutr. 2011;105:1704-11.

7. Tavares EM, Rifas-Shiman SL, Belfort MB, Kleinman KP, Oken E, Gillman MW. Weight status in the first six months of life and obesity at 3 years. Pediatrics. 2009;123(4):1177-83.

8. Stettler $\mathrm{N}$, lotova V. Early growth patterns and long-term obesity risk. Curr Opin Clin Nutr Metab Care. 2010;13(3):294-9.

9. Dattilo A, Birch L, Krebs NF, Lake A, Taveras EM, Saavedra JM. Need for early intervention in the prevention of pediatric overweight: a review and upcoming directions. J Obes. 2012;2012:123023.

10. Birch LL. Development of food acceptance patterns in the first years of life. Proc Nutr Soc. 1998;57:617-24.

11. Fox MK, Pac S, Devaney B, Jankowski L. Feeding infants and toddlers study: What foods are infants and toddlers eating? J Am Diet Assoc. 2004;104 Suppl 1:S22-30

12. Siega-Riz AM, Deming DM, Reidy KC, Fox MK, Condon E, Briefel RR. Food consumption patterns of infants and toddlers: Where are we now? J Am Diet Assoc. 2010;110 Suppl 3:S38-51.

13. Fox MK, Condon E, Briefel RR, Reidy KC, Deming DM. Food consumption patterns of young preschoolers: Are they starting off on the right path? J Am Diet Assoc. 2010;110 Suppl 3:S52-9.

14. Deming DM, Briefel RR, Reidy KC. Infant feeding practices and food consumption patterns of children participating in WIC. J Nutr Educ Behav. 2014;46 Suppl 3:S29-37.

15. World Health Organization. Report of an Expert Consultation. The optimal duration of exclusive breast-feeding. Geneva, Switzerland: World Health Organization; 2002.

16. Pan American Health Organization. Guiding principles for complementary feeding of the breastfed child. Washington, DC: Pan American Health Organization, World Health Organization, Division of Health Promotion and Protection, Food and Nutrition Program; 2001.

17. Mexican Oficial Standard NOM-043-SSA2-2012, Basic health services. Promotion and health education to food. Criteria to provide guidance. Diario Oficial de la Federación; 2013: p. 24-48.

18. American Academy of Pediatrics, Section on Breastfeeding. Policy Statement: Breastfeeding and the use of human milk. Pediatrics. 2012;129(3):e827-41.

19. American Academy of Pediatrics, Committee on Nutrition. Complementary Feeding. In: Kleinman RE, Greer FR, editors. Pediatric Nutrition Handbook, 7th edition. Elk Grove Village, IL: American Academy of Pediatrics; 2014. p. 123-39.

20. Baker JL, Michaelsen KF, Rasmussen M, Sorensen TIA. Maternal prepregnant body mass index, duration of breastfeeding, and timing of complementary food introduction are associated with infant weigh gain. Am J Clin Nutr. 2004;80:1579-88.

21. Taveras EM, Rifas-Shiman SL, Scanlon KS, Grummer-Strawn LM, Sherry B, Gilman MW. To what extent is the protective effect of breastfeeding on future overweight explained by decreased maternal feeding restriction. Pediatrics. 2006;118(6):2341-8.

22. James DC, Lessen R. Position of the American Dietetic Association: promoting and supporting breastfeeding. J Am Diet Assoc. 2009;109(11):1926-42.

23. Gubbels JS, Thijs C, Stafeu A, van Buuren S, Kremers SP. Association of breastfeeding and feeding on demand with child weight status up to 4 years. Int J Pediatr Obes. 2011;6:e515-22.

24. Ong KK, Emmett PM, Noble S, Ness A, Dunger DB, the ALSPAC Study Team. Dietary energy intake at the age of 4 months predicts postnatal weight gain and childhood body mass index. Pediatrics. 2006;117(3):e503-8.

25. Sloan S, Gildea A, Stewart M, Sneddon H, Iwaniec D. Early weaning is related to weight and rate of gain in infancy. Child Care Health Dev. 2008;34:59-64.

26. Brophy S, Cooksey R, Gravenor MB, Mistry R, Thomas N, Lyons RA, et al. Risk factors for childhood obesity at age 5: Analysis of the Millennium Cohort Study. BMC Pub Health. 2009;9:467.

27. Huh SY, Rifas-Shiman SL, Taveras EM, Oken E, Gilman MW. Timing of solid food introduction and risk of obesity in preschool-aged children. Pediatrics. 2011;127:e544-51.

28. Warner ML, Harley A, Bradman G, Vargas G, Eskenazi B. Soda consumption and overweight status of 2-year-old Mexican-American children in California. Obesity. 2006;14:1966-74.

29. Malik VS, Willett WC, Hu FB. Sugar sweetened beverages and BMI in children and adolescents: reanalysis of a meta-analysis. Am J Clin Nutr. 2009;89(1):438-9. 
30. Jimenez-Cruz A, Bacardi-Gascon M, Pichardo-Osuna A, Mandujano-Trujillo Z, Castillo-Ruiz O. Infant and toddlers' feeding practices and obesity amongst low-income families in Mexico. Asia Pac J Clin Nutr. 2010;19(3):316-23.

31. Wosje KS, Khoury RP, Clayor RP, Copeland KA, Hornung RW, Daniels SR, et al. Dietary patterns associated with fat and bone mass in young children. Am J Clin Nutr. 2010;92(2):294-303.

32. Acharya K, Feese M, Franklin F, Kabagambe EK. Body mass index and dietary intake among Head Start children and caregivers. J Am Diet Assoc. 2011; 111:1314-21.

33. Saavedra JM, Deming D, Dattilo A, Reidy K. Lessons from the Feeding Infants and Toddlers Study in North America: What children eat, and implications for obesity prevention. Ann Nutr Metabol.

2013:62 Suppl 3:27-36.

34. Gonzalez de Cossio T, Escobar-Zaragoza L, Gonzalez-Castell LD, Rivera-Dommarco JA. [Article in Spanish] Infant feeding practices and deterioration of breastfeeding in Mexico. Salud Publica Mex. 2013;55 Suppl 2:S170-9.

35. González de Cossío T, Escobar-Zaragoza L, González-Castell D, Reyes-Vázquez $\mathrm{H}$, Rivera-Dommarco JA. Breastfeeding in Mexico was stable, on average, but deteriorated among the poor, whereas complementary feeding improved: results from the 1999 to 2006 National Health and Nutrition Surveys. J Nutr. 2013;143(5):664-71.

36. Ramirez-Silva I, Rivera JA, Ponce X, Hernandez-Avila M. Fruit and vegetable intake in the Mexican population: Results from the Mexican National Health and Nutrition Survey 2006. Salud Publica Mex. 2009;51 Suppl 4:S574-85.

37. Jiménez-Aguilar A, Gaona-Pineda EB, Mejia-Rodriguez F, Gomez-Acosta LM, Mendez-Gomez Humaran I, Flores-Aldana M. Consumption of fruits and vegetables and health status of Mexican children from the National Health and Nutrition Survey 2012. Salud Publica Mex. 2014;56 Suppl 2:S103-12.

38. Stern D, Piernas C, Barquera S, Rivera JA, Popkin BM. Caloric beverages were major sources of energy among children and adults in Mexico, 1999-2012. J Nutr. 2014;144:949-56.

39. Romero-Martinez M, Shamah-Levy T, Franco-Nunez A, Villalpando S, Cuevas-Nasu L, Gutierrez JP, et al. National Health and Nutrition Survey 2012: design and coverage. Salud Publica Mex. 2013;55 Suppl 2:S332-40.

40. United States Department of Agriculture. USDA national nutrient database for standard reference. Beltsville, MD.: USDA; 2011.

41. Subar AF, Krebs-Smith SM, Cook A, Kahle LL. Dietary sources of nutrients among US children, 1989-1991. Pediatrics. 1998;102:913-23.

42. ESPGHAN Committee on Nutrition, Agostoni C, Braegger C, Decsi T, Kolacek S, Koletzko B, et al. Breast-feeding: A commentary by the ESPGHAN Committee on Nutrition. J Pediatr Gastroenterol Nutr. 2009;49(1):112-25.

43. Agostoni C, Decsi T, Fewtrell M, Goulet O, Kolacek S, Koletzko B, et al. Complementary feeding: a commentary by the ESPGHAN Committee on Nutrition. J Pediatr Gastroenterol Nutr. 2008;46(1):99-110.

44. Monterrosa EC, Pelto GH, Frongillo EA, Rasmussen KM. Constructing maternal knowledge frameworks. How mothers conceptualize complementary feeding. Appetite. 2012;59:377-84.

45. Sacco LM, Caufield LE, Gittelsohn J, Martinez H. The conceptualization of perceived insufficient milk among Mexican mothers. J Hum Lact. 2006;22(3):277-86.

46. Bueno-Gutierrez D, Chantry C. 'Life does not make it easy to breast-feed': using the socio-ecological framework to determine social breast-feeding obstacles in a low-income population in Tijuana, Mexico. Public Health Nutr. 2015;5:1-15

47. Bueno-Gutierrez D, Chantry C. Using the socio-ecological framework to determine breastfeeding obstacles in a low-income population in Tijuana, Mexico: healthcare services. Breastfeed Med. 2015;10(2):124-31.

48. Wutich A, McCarty C. Social networks and infant feeding in Oaxaca, Mexico. Maternal Child Nutr. 2008;4:121-35.

49. Pantoja-Mendoza IY, Meléndez G, Guevara-Cruz M, Serralde-Zúñiga AE. Review of complementary feeding practices in Mexican children. Nutr Hosp. 2015;31(2):552-8.

50. Black RE, Allen LH, Bhutta ZA, Caulfield LE, de Onis M, Ezzati M, et al. Maternal and child undernutrition: global and regional exposures and health consequences. Lancet. 2008;371:243-60.

51. Black RE, Victora CG, Walker SP, Bhutta ZA, Christian P, de Onis M, et al. Maternal and child undernutrition and overweight in low-income and middle-income countries. Lancet. 2013;382:427-51.

52. Woo JG, Martin LJ. Does Breastfeeding Protect Against Childhood Obesity? Moving Beyond Observational Evidence. Current Obesity Reports. 2015;4(2):207-16
53. Grummer-Strawn LM, Scanlon KS, Fein SB. Infant feeding and feeding transitions during the first year of life. Pediatrics. 2008;122 Suppl 2:S36-42.

54. Hendricks K, Briefel R, Novak T, Ziegler P. Maternal and child characteristics associated with infant and toddler feeding practices. J Am Diet Assoc. 2006;106 Suppl 1:S135-48.

55. Beauchamp GK, Mennella JA. Flavor perception in human infants: developmental and functional signficance. Digestion. 2011;83 Suppl 1:1-6.

56. Scott JA, Chih TY, Oddy WH. Food variety at 2 years of age is related to duration of breastfeeding. Nutrients. 2012;4(10):1464-74.

57. Raisler J, Alexander C, Ocampo P. Breastfeeding and infant illness: a dose-response relationship. Am J Public Health. 1999;81(1):25-30.

58. Mexican Oficial Standard NOM-043-SSA2-2005. Basic Health Services. Promotion and Health Education in Foods. Criteria to Provide Education. Diario Oficial de la Federación; 2006: p. 32-49.

59. Griebler U, Bruckmüller MU, Kien C, Dieminger B, Meidlinger B, Seper K, et al. Health effects of cow's milk consumption in infants up to 3 years of age: a systematic review and meta-analysis. Public Health Nutr. 2015;20(5):1-15

60. de la Cruz-Góngora V, Villalpando S, Mundo-Rosas V, Shamah-Levy T. Prevalence of anemia in Mexican children and adolescents: Results from three national surveys. Salud Publica Mex. 2013;55 Suppl 2:S180-9.

61. Pasillas-Torres EM, Rodriguez-Ortega E. Childhood anemia in Mexico: A public health problem at all socioeconomic levels. Bol Med Hosp Infant Mex. 2014;71(2):95-102.

62. Oliveira MAA, Osorio MM. Cow's milk consumption and iron deficiency anemia in children. J Pediatr. 2005;81(5):361-67.

63. Przyrembel $\mathrm{H}$. Timing of introduction of complementary food: short- and long-term health consequences. Ann Nutr Metab. 2012;60 Suppl 2:8-20.

64. Allen LH. Global dietary patterns and diets in childhood: implications for health outcomes. Ann Nutr Metab. 2012;61 Suppl 1:29-37.

65. Piernas C, Miles DR, Deming DM, Reidy KR, Popkin BM. Estimating usual intakes mainly affects the micronutrient distribution among infants, toddlers and pre-schoolers from the 2012 Mexican National Health and Nutrition Survey. Public Health Nutr. 2015;18:1-10.

66. Eichler K, Weiser S, Ruthemann I, Bruger U. Effects of micronutrient fortified milk and cereal food for infants and children: a systematic review. BMC Public Health. 2012;12:506.

67. Branum AM, Rossen LM. The contribution of mixed dishes to vegetable intake among US children and adolescents. Public Health Nutr. 2013;17(9):1-8

68. Krebs-Smith SM, Guenther PM, Subar AF, Kirkpatrick SI, Dodd KW. Americans do not meet federal dietary recommendations. J Nutr. 2010;140(10):1832-8.

69. Duffey KJ, Rivera JA, Popkin BM. Snacking is prevalent in Mexico. J Nutr. 2014;144:1843-9.

70. Shim J-S, Oh K, Kim HC. Dietary assessment methods in epidemiologic studies. Epidemiol Health. 2014;36:e2014009.

71. Castell GS, Serra-Majem L, Ribas-Barba L. What and how much do we eat? 24-hour dietary recall method. Nutr Hosp. 2015;31 Suppl 3:46-8

72. Popkin BM, Lu B, Zhai F. Understanding the nutrition transition: measuring rapid dietary changes in transitional countries. Pub Health Nutr. 2002;5:947-53.

\section{Submit your next manuscript to BioMed Central and we will help you at every step:}

- We accept pre-submission inquiries

- Our selector tool helps you to find the most relevant journal

- We provide round the clock customer support

- Convenient online submission

- Thorough peer review

- Inclusion in PubMed and all major indexing services

- Maximum visibility for your research

Submit your manuscript at www.biomedcentral.com/submit 